Article

\title{
Agro-Pruning for Energy as a Link between Rural Development and Clean Energy Policies
}

\author{
Biljana Kulišić ${ }^{1, * \mathbb{D}}$, Tajana Radić ${ }^{2}$ and Mario Njavro ${ }^{3}$ \\ 1 Department for Renewable Energy Sources, Energy Efficiency and Environmental Protection, \\ Energy Institute Hrvoje Pozar, 10000 Zagreb, Croatia \\ 2 Croatian Chamber of Agriculture, 10000 Zagreb; Croatia; tajana.radic@komora.hr \\ 3 Department of Management and Rural Entrepreneurship, University of Zagreb Faculty of Agriculture, \\ 10000 Zagreb, Croatia; mnjavro@agr.hr \\ * Correspondence: bkulisic@eihp.hr; Tel.: +385-(0)1-6326-169
}

Received: 7 April 2020; Accepted: 18 May 2020; Published: 21 May 2020

check for updates

\begin{abstract}
Agrarian pruning and plantation removal (APPR) is a common residue from pomo-technical maintenance of orchards, vineyards, and olive groves, frequently overlooked by the energy sector. This paper sheds new light on the socio-economic role of APPR as solid biofuel. The paper suggests business models that could both alleviate energy poverty in rural areas and increase the competitiveness of perennial crop (fruits, olives, vine) production. The effects of mobilizing APPR potential via business models are estimated at the micro (households' income) and macro (number of households affected, size of the investment, tax effect, $\mathrm{CO}_{2 \text { eq }}$ savings) levels in the Croatian setting. Contrary to classical energy planning, the paper provides an approach that fosters local use of bioenergy by linking rural development with renewable energy end-use. The approach linked pruning energy potential with $47 \%$ of Croatian rural households which allows creating an evidence-based policy for rural development utilizing APPR as a sustainable solid biofuel. The most attractive business model for Croatian rural areas is utilization of APPR as a solid biofuel. It could be used as an energy poverty alleviation measure, allowing savings per heating season equivalent to $5 \%-11 \%$ of the average disposable income per household. Net APPR influence at VAT tax is estimated at 5.5 million euro $\cdot y^{-1}$. The paper proves that using average values for APPR in energy planning could be misleading.
\end{abstract}

Keywords: pruning; solid biofuel; energy poverty; rural development; energy planning

\section{Introduction}

Energy potential from woody biomass originated from regular care of orchards, vineyards, and olive groves is frequently overlooked both at the micro (local source of renewable energy and additional farm income) and macro (energy planning) levels. The research that looks at bioenergy potential from agriculture at a macro level is focused on more abundant agro-residues from crop production (e.g., straw) [1-4] and manure [5,6]. Numerous studies have been conducted to estimate the energy potential from agrarian pruning and plantation removal (APPR) focusing either on a geographical area (country [7], region [4], macro-region [8-11]) or on a certain type of APPR from vineyards [7,12], specific fruit plantation [13], or olive groves [14,15]. Indeed, when comparing the energy potential from APPR to the energy demand in the same geographical area, the percentage of potential replacement of fossil fuels is negligible. For illustration, theoretical pruning potential estimated at $227.2 \mathrm{PJ} \cdot \mathrm{y}^{-1}[10]$ represented $0.33 \%$ of the total energy supply in the EU-28 2017 [16]. Adding to that spatial distribution, seasonal dynamics, and variation in quality and quantity, APPR does not represent an attractive "low hanging fruit" to decarbonize our society, from that perspective. 
This paper sheds a different light on the socio-economic role of using APPR as solid biofuel by creating business models that could help alleviate energy poverty in rural areas or increase the competitiveness of fruit, olive, and wine production. Namely, when connecting energy supply contained in APPR with the end-use energy demand at the location where such biomass originates, the setting is quite different. If APPR is used for heating of the EU-28 rural households, they could supply $11.55 \%$ and $50 \%$ of space and water heating demand, respectively [17]. This estimation is based on $64.1 \%$ and $14.8 \%$ of space and water heating, respectively, in the final energy consumption in the EU-28 households [17]. In Croatia, $28 \%$ of the population lives in rural areas, of those $80 \%$ live in family houses [18]. Yet, heating consumption among EU-28 varies from $15.7-20 \mathrm{koe} \cdot \mathrm{m}^{-2}$ in Latvia and Hungary to less than $5 \mathrm{koe} \cdot \mathrm{m}^{-2}$ in Spain, Portugal, and Malta [19]. Only connecting APPR with heating consumption would be also misleading as Latvia and Hungary have 5.9 kha and 2368 kha under permanent crops for human consumption, respectively [20]. Currently, EU-28 uses $14 \%$ of oil and petroleum products in the final energy consumption in the residential sector for space heating in 2017 [16]. The niche setting of using APPR as a renewable, locally available solid biofuel for rural household heating is different than the wider view from the energy balances.

Parallel to the energy aspects of APPR, our approach discusses different business models of APPR use that would motivate mobilization of APPR potential. A business model describes the rationale of how an organization creates, delivers, and captures value [21]. This paper contributes to the descriptive elaboration and economic analysis of the business model of APPR. The attractiveness of the business model would determine its replicability rate in a given legal and socio-economic setting. Existing knowledge provides several well-elaborated and verified frameworks of business models, design patterns, and tools to build a business model. Although many case studies revealed several types of circular business actions or models, these models have limited transferability [22,23]. There are very few studies covering, in a more comprehensive manner, how a circular business model framework should look. Lewandovski (2015) investigated the eight sub-domains of research on circular business models to redefine the components of the business model canvas in the context of the circular economy [22]. None of these reviewed studies has provided satisfactory answers to the following questions: How may the principles of the circular economy be applied to a business model? This paper builds on stakeholders' responses on business models [24-26] recorded during the implementation of the uP_running project [27] in Croatia (2016-2019). It used the triple fit challenge [22] to assess the attractiveness of circular economy business models to the pruning owners. It aimed to unlock the European potential of woody biomass residues produced by APPR and guide policy makers on how to integrate its energy end-use as a solid biofuel, free of sustainability controversies. The project identified key stakeholders and suggested applicable business models based on the case studies around Europe in order to contribute sustainable energy use and farm competitiveness.

This paper lays out aspects of four main options on how to utilize APPR as solid biofuel that are further shaped in eight business models whose replicability rates will depend both on rational (e.g., economics, legal boundaries) and non-rational (human) factors [4,28]. The effects of mobilizing APPR potential via business models are estimated at the micro (disposable income) and macro (number of households affected, size of the investment, net VAT effect, energy balances impacts) levels for Croatian rural households. The selection met the triple fit challenge of a circular economy business canvas [22]. Finally, the paper provides a heuristic methodology that allows creating an evidence-based policy for rural development utilizing APPR as solid biofuel.

\section{Materials and Methods}

Mobilizing APPR as a bioenergy source requires a different approach than other biomass sources as the effects are greater at the rural development side than on the energy sector as a whole. The proposed stepwise approach creates synergy between (renewable) energy policy and rural development; it consists of the 8 steps, starting with the energy balances at the macro level, reaching as far as to the individual rural 
household with a perennial grove and bringing the effects back to the macro level (Table 1). The approach concentrates on the effects of engaging an already available solid biomass source for bioenergy.

Each step is described in the following sub-sections, including formulas and sources on how to calculate and interpret the outputs.

Table 1. Stepwise approach in creating synergy between renewable energy and rural development policy in utilizing agrarian pruning and plantation removal (APPR) as solid biofuel.

\begin{tabular}{|c|c|c|}
\hline Step & Action & Output \\
\hline 1 & $\begin{array}{l}\text { Linking APPR potential with energy demand } \\
\text { at the location of origin }\end{array}$ & $\begin{array}{l}\text { Share of APPR primary energy in final energy } \\
\text { demand in rural households at the national level }\end{array}$ \\
\hline 2 & $\begin{array}{l}\text { Allocating APPR primary energy most } \\
\text { suitable end-use }\end{array}$ & $\begin{array}{l}\text { Household final energy consumption by fuel type } \\
\text { and end-use of energy }\end{array}$ \\
\hline 3 & Positioning APPR as fuel at the fuel market & Ranking of fuels by the gross price of energy \\
\hline 4 & $\begin{array}{l}\text { Defining business models with the highest } \\
\text { replication probability }\end{array}$ & $\begin{array}{l}\text { An outlook of feasible business models to utilize } \\
\text { APPR as solid biofuel }\end{array}$ \\
\hline 5 & $\begin{array}{l}\text { Sizing the annual APPR demand with a size } \\
\text { of the perennial grove }\end{array}$ & $\begin{array}{l}\text { An average area of orchard, vineyard, and olive } \\
\text { grove to meet the household's energy consumption } \\
\text { by end-use of energy }\end{array}$ \\
\hline 6 & Sizing replication rate & Estimation of the market for feasible business models \\
\hline 7 & Estimating effects at the micro-level & $\begin{array}{c}\text { Changes in household's income occurred by using } \\
\text { APPR as solid biofuel }\end{array}$ \\
\hline 8 & Estimating effects at the macro-level & $\begin{array}{c}\text { Changes in VAT, energy imports, newly created } \\
\text { demand for utilities; } \mathrm{CO}_{2 \text { eq }} \text { savings }\end{array}$ \\
\hline
\end{tabular}

\subsection{Linking APPR Potential with Energy Demand at the Location of Origin}

APPR potential will depend not only on the area covered with perennial crops but also on the thinning practice, season, and growing type (extensive, intensive). At this step, the theoretical potential range of winter APPR would suffice. The considered APPR potential is allocated from the uP_running project [27] with adaptation $[29,30]$ to the net calorific (heating) value of the dry matter, to make it comparable with the values recorded as the energy balances [16]. Energy balances are considered a starting point for the development of energy sector policies [16].

Households represent one of the four sub-categories of "other" sectors that consume energy. The energy consumed by households is represented in the final energy demand of energy balances. Final energy demand is not directly comparable with theoretical APPR potential which represents primary energy contained in APPR as a fuel or energy carrier. Final energy is the energy that is used by a consumer, after reducing the primary energy of fuel for energy conversion, transformation, delivery, losses, etc. [16]. Assuming 80\% efficiency of energy conversion for APPR, it is possible to relate the primary energy of APPR with energy consumption in rural households:

$$
\mathrm{FE}_{\text {pruning }}=\mathrm{PE}_{\text {pruning }} \times \eta
$$

where $\mathrm{FE}_{\text {pruning }}=$ final energy potential of pruning, $\mathrm{PE}_{\text {pruning }}=$ theoretical energy potential of APPR, $\eta=$ efficiency of energy conversions (\%).

$$
\mathrm{FEC}_{\mathrm{rh}}=\mathrm{FEC}_{\mathrm{h}} \times \mathrm{rh}
$$

where $\mathrm{FEC}_{\mathrm{rh}}=$ final energy consumption in rural households, $\mathrm{FEC}_{\mathrm{h}}=$ final energy consumption in households, $\mathrm{rh}=$ share of rural households in total households (\%).

$\mathrm{FE}_{\text {pruning }}$ is comparable with $\mathrm{FEC}_{\mathrm{rh}}$ and serves as a good indicator of how important a role energy from APPR could have in energy policies in rural areas. Further, APPR energy could be tailored towards specific use in the household: biomass as biofuel can be used for space and water heating as well as cooking. 
To calculate the share of space heating, water heating, and cooking end-use of energy consumption in dwellings, respectively, the following formulas are used:

FECrhHEAT $=$ FECrh $\cdot x \%$ space heating in end-use of energy consumption in dwellings

FECrhWATER $=$ FECrh $x \%$ water heating in end-use of energy consumption in dwellings

FECrhCOOKING $=$ FECrh $x \%$ cooking in end-use of energy consumption in dwellings

All values are expressed in rounded numbers as they serve only as a guide towards the end-use of APPR.

\subsection{Allocating APPR Primary Energy to the Most Suitable End-Use}

To obtain energy demand structure, final energy consumption per rural household ( $\left.\mathrm{FEC}_{\text {perRH }}\right)$ is multiplied with shares of energy uses (space heating, water heating, space cooling, cooking, lighting and electrical appliances, and other end-uses (mainly covering uses of energy by households outside the dwellings themselves)). Eurostat [19] provides data on FEC $\mathrm{perRH}_{\text {at }}$ at the EU-28 and member state levels, while the International Energy Agency (IEA) provides global level data. Part of the main energy products (end-use energy) in the final energy consumption in the households $\left(\mathrm{FEC}_{h}\right)$ for each type of end-use allows seeing the structure of fuels used for space heating, space cooling, water heating, cooking, lighting and appliance use, and other end-uses. APPR, as a solid biofuel, will find its place either as substituting oil and gas end-uses or supplementing renewables and wastes categories. It is very likely that space heating will take most of the final energy demand in rural households $\left(\mathrm{FEC}_{\mathrm{rh}}\right)$ but Mediterranean rural areas would also use for other heat demand, such as cooking and hot water preparation. The share of fuels in the final energy consumption in the residential sector for space heating gives an overview of the fuel mixture used for space heating $[19,20]$.

\subsection{Positioning APPR as Solid Biofuel at the Fuel Market}

To allocate the attractiveness of fuel switching, substitution, or supplement options for a rural household, gross energy prices per fuel for heating are compared. Gross energy prices represent the price paid per unit of energy by a household., considering the losses for energy conversion. It allows comparison of fuel prices not only by their primary energy content but also considering the losses that occurred for energy conversion.

Table 2 provides indicative coefficients to give a rough estimation on the market prices, if more precise data on heating systems are not available. It states the equivalent useful heat energy monetary value for each monetary unit of primary energy.

Table 2. Useful heat energy monetary equivalent to the fuel price by fuel type (source: own calculations based on reference [31]).

\begin{tabular}{ccc}
\hline Type of Fuel for Heating & $\begin{array}{c}\text { Energy Efficiency of the } \\
\text { Conversion [31] }\end{array}$ & $\begin{array}{c}\text { Useful (Heat) Energy Monetary } \\
\text { Equivalent to the Fuel Price }\end{array}$ \\
\hline Electricity & $100 \%$ & $100 \%$ \\
natural gas & & \\
- old stoves & $<75 \%$ & $125 \%$ \\
- new stoves & $75-85 \%$ & $120 \%$ \\
LPG-propane butane & $85 \%[32]$ & $115 \%$ \\
LPG-butane & $90 \%$ & $110 \%$ \\
light heating oil & $>90 \%$ & $110 \%$ \\
fuelwood & & \\
- old stoves & $70-80 \%$ & $130 \%$ \\
-new stoves & $70-85 \%$ & $120 \%$ \\
briquettes & $85 \%$ & $125 \%$ \\
pellets & $>90 \%$ & $110 \%$ \\
\hline
\end{tabular}




\subsection{Defining Business Models with the Highest Replication Probability}

In rural areas, households are usually set either in the vicinity of a farm or integrated within the farm facilities with a single connection point for energy supply (electricity, gas). An APPR owner has four options to utilize the primary energy captured in APRR: (1) use it in direct combustion to generate heat; (2) use direct combustion to generate both heat and electricity in a cogeneration (combined heat and power or CHP) unit; (3) produce agro-pellets for market; and (4) sell APPR.

The attractiveness of each option at the local level will depend, in accordance to the triple fit challenge [22], not only on the balanced cost and revenue streams but also on the age, education, and financial potency plus tradition, perceptions, and values on using APPR, as well as on the prices of the alternatives. The legal setting would also determine the feasibility of each option. Each of the business models is evaluated using the pay-back (PB) period-the amount of time it takes to recover the cost of an investment. Table 3 indicates the options for increasing competitiveness in the primary production of fruit, olives, and wine with APPR utilization

Table 3. Business models with cost and benefits.

\begin{tabular}{|c|c|c|}
\hline Business Model & Costs & Benefits \\
\hline \multicolumn{3}{|l|}{$\begin{array}{l}\text { Use APPR for direct combustion to } \\
\text { generate heat }\end{array}$} \\
\hline Fuel supplement option & No investment needed. & Savings equivalent to the prices of wood logs \\
\hline Fuel-switching option & $\begin{array}{l}\text { Investment of } 4730 \text { euro [32] needed } \\
\text { for heating system adaptations. }\end{array}$ & $\begin{array}{l}\text { Savings for the household space heating } \\
\text { equivalent to the fuels with gross energy prices } \\
\text { higher than wood logs. }\end{array}$ \\
\hline \multirow{3}{*}{$\begin{array}{l}\text { Direct combustion of APPR to } \\
\text { generate both heat and electricity } \\
\text { in a CHP unit }\end{array}$} & \multirow[b]{2}{*}{$\begin{array}{l}\text { Investment for a } 50 \mathrm{~kW} \text { unit: } \\
4700 \text { euro/kW for CHP unit and } \\
2 \times 2500 \mathrm{~W} \text { home chippers at } 250 \text { euro } \\
\text { each. Total investment: } 235,500 \text { euro. } \\
\text { Additional costs for heating system } \\
\text { adaptations per household: } 4730 \text { euro. }\end{array}$} & Fuel-switching options: \\
\hline & & $\begin{array}{l}\text { (1) all produced electricity is used at the } \\
\text { household, meeting the total needs of the } \\
\text { household for all end-use consumption; } \\
\text { (2) selling the excess energy via } \\
\text { micro-grid system; } \\
\text { (3) for heating, sales of electricity at a }\end{array}$ \\
\hline & $\begin{array}{l}\text { Fuel-switching option for heating } \\
\text { with establishing an electric vehicle } \\
\text { filling station. Additional investment } \\
\text { for a } 50 \mathrm{~kW} \text { fast-charging station: } \\
20,000 \text { euro. Investment in an } \\
\text { e-vehicle: } 35,000 \text { euro. }\end{array}$ & $\begin{array}{l}\text { (3) for heating, sales of electricity at a } \\
\text { privileged renewable electricity price; } \\
\text { (4) if heating supply surpasses individual } \\
\text { household demand, requires a micro-district } \\
\text { heating system or on-farm heating demand; } \\
\text { (5) electric vehicle filling station, generating } \\
\text { income from electricity sales without grid } \\
\text { connection option; and } \\
\text { (6) switching to the e-mobility with costless } \\
\text { fuel with possible heat use }\end{array}$ \\
\hline $\begin{array}{l}\text { Produce agro-pellets from APPR } \\
\text { for market }\end{array}$ & $\begin{array}{l}\text { Investment in a } 500 \mathrm{~kg} \cdot \mathrm{h}^{-1} \text { pellet } \\
\text { production line: } 25,000 \text { euro. } \\
\text { Investment in a tractor attached } \\
\text { chipper, with the ability to chip APPR } \\
\text { with }<127 \mathrm{~mm} \text { diameter at } 6-7 \mathrm{~m}^{3} \cdot \mathrm{h}^{-1} \text { : } \\
1000 \text { euro. Total investment } \\
26,000 \text { euro. }\end{array}$ & Sales price of agro-pellets \\
\hline \multirow{2}{*}{ Selling APPR as chips for the market } & $\begin{array}{l}\text { Holdings with }<5 \text { ha: Investment in a } \\
2500 \mathrm{~W} \text { wood chipper, with the ability } \\
\text { to chip APPR with }<45 \mathrm{~mm} \text { diameter: } \\
250 \text { euro. }\end{array}$ & \multirow{2}{*}{ Sales price of chips } \\
\hline & $\begin{array}{l}\text { Holdings with }>5 \text { ha: Investment in a } \\
\text { tractor attached chipper, with the } \\
\text { ability to chip APPR with }<127 \mathrm{~mm} \\
\text { diameter at } 6-7 \mathrm{~m}^{3} \mathrm{~h}^{-1}: 1000 \text { euro. }\end{array}$ & \\
\hline
\end{tabular}

\subsection{Sizing the Annual APPR Demand with the Size of the Perennial Grove}

The alternatives for APPR utilization would be related to the quantity available (technical potential) and competitiveness of the (bundle) of produce (economic potential). APPR quantity is directly related to the size of the perennial crop plantation but varies depending on climate zone, crop variety, and landscape. The feasibility of the business models can be assessed with different approaches, depending on the APRR data availability. Table 4 provides aggregated minimum and maximum values 
for EU-28 per perennial crop plantations only, including the averages (mean) and the most frequent value (mode). These values provide good indicators to proceed towards various business models, beyond bioenergy. For energy use of APPR, it is better to use values from Table 5. Continuing on Garciá-Galindo et al. [33], results on APPR productivity ratios relative to the surface (t.ha ${ }^{-1} \mathrm{~d} . \mathrm{m}$.) by crop group by country in EU-28, and lower heating values (LHV) of the selected APPR wood.

Table 4. APPR availability relative to the surface ratio adjusted (t.ha ${ }^{-1}$ d.m.) (source: adaptation of data from reference [33]).

\begin{tabular}{ccccc}
\hline & Min & Max & Mean & Mode \\
\hline Vineyards & 1.05 & 1.69 & 1.16 & 1.05 \\
Olive groves & 1.10 & 1.47 & 1.12 & 1.10 \\
Orchards (excl. citrus, nuts) & 1.50 & 2.80 & 1.89 & 1.50 \\
Citrus fruits & 1.32 & 4.72 & 1.83 & 1.32 \\
Nuts & 0.50 & 1.00 & 0.70 & 0.50 \\
\hline
\end{tabular}

Table 5. Lower heating value (LHV) of the selected APPR wood and the average (source: adaptation of data from reference [33]).

\begin{tabular}{ccccccc}
\hline LHV $\left(\mathbf{M J} \cdot \mathbf{k g}^{-\mathbf{1}}\right)$ & Fruit & Nuts & Citrus & Olive & Vineyard & Average \\
\hline $\mathrm{LHV}_{\mathrm{DM}}(\mathrm{W}=0 \%)$ & 17.5 & 17.2 & 17.2 & 16.7 & 16.8 & 17.08 \\
$\mathrm{LHV}_{\mathrm{DM}}(\mathrm{W}=20 \%)$ & 13.5 & 13.3 & 13.3 & 12.9 & 13.0 & 13.2 \\
\hline
\end{tabular}

(1) APPR for direct combustion to generate heat for the household: Data for heat demand in our model are based on national data (EIHP, own data). Using the result on final energy consumption in rural households, $\mathrm{FEC}_{\mathrm{rh}}$ from Equation (2), and dividing it by the number of households, it would give a rough estimation of an average heat demand per rural household.

(2) Direct combustion of APPR to generate both heat and electricity in a CHP plant: For a $50 \mathrm{~kW} \mathrm{CHP}$ unit with $30 \%$ and $40 \%$ of electricity and heat efficiency, respectively, and 3000 operational hours only during the heating season, it would need roughly $33 \mathrm{t}$ of APPR per heating season. It is reasonable to expect that both heat and electricity generated in a $50 \mathrm{~kW} \mathrm{CHP} \mathrm{would} \mathrm{surpass} \mathrm{the}$ demand of a household tenfold. Assuming $12.2 \mathrm{kWh} \cdot 100 \mathrm{~km}^{-1}$ as e-vehicle consumption, a $50 \mathrm{~kW}$ CHP unit would be a feasible fuel-switching option for the period when the APPR is available.

(3) Production of agro-pellets for the market would be attractive for an APPR owner if the purchase price of pellets is covering the production costs of agro-pellets and the investment in a pellet production facility.

(4) Selling APPR would be an option that would bring the least value added to the owner but also would allow the least effort. The agreement can be either to collect APPR at the plantation or that the owner delivers the APPR to a collection point. Both options will be reflected in the purchasing price.

The paper ranks the business models according to the perceived attractiveness (SPB, adoption factors, legal framework), based on the triple fit [22].

\subsection{Sizing the Replication Rate}

National statistics on the structure of perennial groves, as well as geographical distribution, will identify the replication rate for each business model.

The shortest supply chain would be utilizing one's own APPR for direct combustion in individual stoves or boilers for central heating. From the energy point of view, local combustion of APPR for heat (household heating, hot water preparation, on-farm heat for drying, or district heating with micro-grids) would be the most efficient option to utilize primary energy from APPR, minimizing transportation costs and post-harvesting efforts. A rural filling station for e-vehicles is a feasible 
option for income diversification and decentralization of energy supply, especially in rural areas with fewer capacity distribution grids. A rural filling station is the most advanced business model and in accordance with the EU vision for a decentralized energy supply [34]. The longer supply chain is to produce agro-pellets for the market. The first option allows household savings while the latter options trigger income diversification and increase.

\subsection{Estimating Effects at the Micro Level}

To estimate the savings effect, one must compare the prices of fuels for heating as well as the location where the APPR is occurring. Table 2 provides elements for heating price comparisons. Comparison of the percentage of (rural) households with an inability to keep the home warm [35] would give an indication if APPR for household heating could be an energy poverty alleviation or increase the living comfort measure. The average annual distance traveled by car per country or the EU average of 12,000 km [36] would contrast the electric energy demand with the electricity produced in the CHP unit.

\subsection{Estimating Effects at the Macro Level}

After allocating the most suitable use of APPR in rural households, we use Equations (1) and (2) to calculate the effects on the macro-level in terms of energy savings. In the case of fuel replacement, we estimated the loss of VAT since fuel is not purchased but obtained from its own sources. Also, the gain of VAT in case of stove replacements or vehicle purchasing was estimated. Additional income was estimated with placing APPR as solid biofuel on the market, either as agro-pellets or chips. Based on the estimated additional income with placing APPR as solid biofuel on the market, either as agro-pellets or chips, additional VAT generation was determined. Additional demand for equipment (stoves, pellet lines, wood chippers, filling stations, etc.) should be addressed in the context of the net trade balances.

Fuel replacement affects greenhouse gas (GHG) emissions whose effect can be calculated using the indicators from the European Environmental Agency [37] or national data. If electricity is replaced, the GHG emissions saved would be equivalent to the emissions that occurred during the electricity generation or national electricity generation mix. In 2016, electricity generation's $\mathrm{CO}_{2 \mathrm{eq}}$ emission intensity was 295.8 and $210 \mathrm{~g} \mathrm{CO}_{2 \mathrm{eq}} \cdot \mathrm{kWh}^{-1}$ for the EU-28 and Croatia, respectively [37].

\section{Results and Discussion}

The approach was applied to the EU and Croatian average values to demonstrate how the role of APPR in energy planning could be underestimated when applying the classical approach to energy planning. The methodology was also applied to two NUTS-2 regions: Continental Croatia (HR04) and Adriatic (or Mediterranean) Croatia (HR03) to demonstrate the differences when using the average values. Roughly, Continental Croatia has higher annual heating demand than Adriatic Croatia but natural gas is not available in all of Adriatic Croatia.

According to the data of the Croatian Bureau of Statistics, there were 1.5 million ha of the utilized agricultural area in 2018 (1.03 million ha in the Continental region and 0.455 million ha in the Mediterranean region). The area under perennial crops was 71 thousand ha (37.9 thousand ha in Continental and 38 thousand ha in the Mediterranean region). In the structure of perennial crops, orchards participated with about $2.2 \%$ while vineyards and olive groves had $1.4 \%$ and $1.25 \%$ respectively. In case of the absence of national APPR energy potential estimations, there are several EU funded projects, such as Biomass Futures [9], S2Biom [10], and uP_running [27] that give APPR potential both at the EU-28 and member state level. Summer APPR contains a challenging leaf and moisture content to be used for small-scale, mature bioenergy facilities.

Applying the Equations (1) and (3) on the theoretical APPR potential of 227.2 PJ. $\mathrm{y}^{-1}$ and $2.01 \mathrm{PJ} \cdot \mathrm{y}^{-1}$ for the EU-28 and Croatia, respectively [33], the significance of energy potential of APPR varies but with a specific pattern for each category (Table 6). 
Table 6. Linking APPR potential with energy demand in rural households, EU and Croatia (HR).

\begin{tabular}{ccccccc}
\hline Area & $\begin{array}{c}\text { PE }_{\text {pruning }} \\
(\mathbf{P J})\end{array}$ & $\begin{array}{c}\mathrm{FE}_{\text {pruning }} \\
(\mathbf{P J})\end{array}$ & $\begin{array}{c}\mathrm{FEC}_{\mathbf{h}} \\
\mathbf{( P J )}\end{array}$ & $\begin{array}{c}\text { Share of APPR in } \mathrm{FEC}_{\mathbf{h}} \\
\mathbf{\%}\end{array}$ & $\begin{array}{c}\text { FEC }_{\text {rh }} \\
\mathbf{( P J )}\end{array}$ & $\begin{array}{c}\text { Share of APPR in } \mathrm{FEC}_{\text {rh }} \\
\text { \% }\end{array}$ \\
\hline $\mathrm{EU}$ & 227.20 & 181.76 & 12,066 & $2 \%$ & 3379 & $5 \%$ \\
$\mathrm{HR}$ & 2.01 & 1.61 & 100 & $2 \%$ & 46 & $4 \%$ \\
\hline
\end{tabular}

The share of APPR in final energy consumption of rural households remains low with $5 \%$ and $4 \%$ for the EU and Croatia, respectively, which is related to the share of rural households in the total number of households which is $28 \%$ and $46 \%$ for the EU-28 and Croatia, respectively. The possible end-use of APPR potential varies when looking at the EU average values and national values (Croatia) (Table 7). In terms of the end-use of thermal energy, Croatian APPR potential could cover $5 \%$ final energy consumption for space heating but one-third for both water heating and cooking. When considering electricity consumption, APPR could cover about a third for electrical appliances and surpass air conditioning energy consumption threefold.

Table 7. Allocating APPR potential as shares (\%) in different end-use in households, EU and Croatia.

\begin{tabular}{cccccc}
\hline Area & Space Heating & Water Heating & Cooking & Electrical Appliances & AC \\
\hline EU & $8 \%$ & $40 \%$ & $1013 \%$ & $36 \%$ & $9 \%$ \\
HR & $5 \%$ & $36 \%$ & $32 \%$ & $30 \%$ & $141 \%$ \\
\hline
\end{tabular}

As a start for evaluation of APPR energy utilization options to the business models, useful heating prices for Croatia (Table 8) were calculated based on the values in Table 2 and current market prices. Table 8 presents gross energy prices for all heating fuels available, by fuel type and energy efficiency of the primary energy conversion.

Table 8. Useful heat energy monetary equivalent to the fuel price by fuel type, Croatia (2019).

\begin{tabular}{|c|c|c|}
\hline Fuel & Gross Energy Price (Eurocent $\mathrm{MJ}^{-1}$ ) & Source \\
\hline natural gas & 1.3728 & [38] \\
\hline woody briquettes & 1.4077 & National yellow-pages [39] \\
\hline electricity-black tariff & 1.5766 & {$[40]$} \\
\hline fuel wood-public forests & 1.6467 & [41] \\
\hline fuel wood-private forests & 1.7486 & \\
\hline wood pellets & 1.8168 & National yellow-pages [39] \\
\hline LPG_-propane butane & 1.9504 & \\
\hline LPG-butane & 2.0221 & [42] \\
\hline light heating oil & 2.2526 & \\
\hline wood residues & 2.8924 & [39] \\
\hline electricity-red tariff & 2.9655 & \\
\hline electricity-blue tariff & 3.2658 & [40] \\
\hline electricity-white tariff & 3.5661 & \\
\hline diesel fuel & 3.090 & [42] \\
\hline
\end{tabular}

The fuel prices in Table 8 indicate the opportunity costs for using APPR in different business models for Croatian APPR owners. The prices of wood (fuelwood from private and public forests) would reflect the savings potential of fuel replacement or supplement. Fuel switching from fossil to renewable solid biofuel would be attractive, especially for electricity, for all fuels but natural gas. Wood chips would reflect the possible market price for APPR.

The business models defined in the methodology are arranged for the EU-28 averages but also placed in the Croatian setting below.

(1) The use of APPR for direct combustion to generate heat 
For the EU average, 0.92 toe per dwelling and $10.1 \mathrm{koe} \cdot \mathrm{m}^{-2}$ of a dwelling of heat are used. Here, we aim at meeting demand with APPR for space heating as the largest share of the average EU-28 end-use thermal demand. As a rule of thumb, a perennial plantation with 2-3 ha (5-6 ha for nuts) would meet the heating demand of an average household in the EU. That is based on $46.22 \mathrm{GJ}$ heating per dwelling, assuming $80 \%$ energy efficiency of a wood stove and heating values. The proxies for relating the household heat demand with the perennial crop plantation area (referring to the APPR availability per hectare (Table 4)) are presented in Table 9. The same table contrasts nationally refined data on household heating consumption in Croatia: Continental (HR04) and Mediterranean (HR03) parts.

Table 9. Average size of a perennial crop plantation meet an average EU household space heating consumption (ha).

\begin{tabular}{cccccccc}
\hline Perennial Plantation & $\begin{array}{c}\text { EU-28 } \\
\text { Min }\end{array}$ & $\begin{array}{c}\text { EU-28 } \\
\text { Max }\end{array}$ & $\begin{array}{c}\text { EU-28 } \\
\text { Mean }\end{array}$ & $\begin{array}{c}\text { EU-28 } \\
\text { Mode }\end{array}$ & $\begin{array}{c}\text { HR04 } \\
\text { Mean }\end{array}$ & $\begin{array}{c}\text { HR03 } \\
\text { Mean }\end{array}$ & HR Mode \\
\hline Vineyards & 1.56 & 2.52 & 2.28 & 2.52 & 3.28 & 1.56 & 2.70 \\
Olive groves & 1.83 & 2.44 & 2.40 & 2.44 & & 1.45 & 2.51 \\
Orchards (excl. citrus, nuts) & 0.96 & 1.79 & 1.42 & 1.79 & 1.39 & 0.66 & 1.15 \\
Citrus fruits & 0.59 & 2.10 & 1.51 & 2.10 & & 1.35 & 2.33 \\
Nuts & 2.75 & 5.50 & 3.93 & 5.50 & 4.00 & 1.91 & 3.29 \\
\hline
\end{tabular}

National values to derive an average size of a perennial crop plantation at NUTS-2 level is based on the door-to-door survey of energy efficiency in households and services [43] and national census on population and households in 2011 [44].

(2) Direct combustion of APPR to generate both heat and electricity in a CHP plant

The annual consumption of electricity per dwelling in the EU-28 average and Croatia is similar: $2266 \mathrm{kWh} \cdot \mathrm{y}^{-1}$ and $2235 \mathrm{kWh} \cdot \mathrm{y}^{-1}$, respectively [17]. A $50 \mathrm{~kW} \mathrm{CHP} \mathrm{unit} \mathrm{would} \mathrm{meet} \mathrm{the} \mathrm{electricity}$ demand of $\sim 20$ of both Croatian and EU-28 average) households.

If the electricity produced from the same CHP unit is to be used to charge an e-vehicle, it would suffice to power a car for $\sim 3700 \mathrm{~km}$ at the time when the APPR is available. In the case of switching one's own car to a hybrid model, it would cover about $30 \%$ of the annual average distance traveled by car of $12,500 \mathrm{~km}$ in Croatia [45]. Annual fuel savings would be equivalent to $30 \%$ savings for a diesel car, or about 1000 euro per year.

APPR demand, according to the different perennial crop plantations, would assume the sizes as shown in Table 10. For the EU-28 average area of 27 ha, perennial crops (excluding 67 ha for nuts) would be needed to supply a $50 \mathrm{~kW} \mathrm{CHP} \mathrm{unit.} \mathrm{For} \mathrm{Croatia,} \mathrm{the} \mathrm{values} \mathrm{for} \mathrm{fruit} \mathrm{orchards} \mathrm{and} \mathrm{nuts}$ significantly vary from the EU-28 mean and mode values since the pruning yields per hectare of fruit and nuts plantations in Croatia are closer to the EU-28 maximum values.

Table 10. Average size of a perennial crop plantation to meet a $50 \mathrm{~kW} \mathrm{CHP} \mathrm{unit} \mathrm{(ha).}$

\begin{tabular}{cccccc}
\hline Perennial Plantation & EU-28 Min & EU-28 Max & EU-28 Mean & EU-28 Mode & HR Average \\
\hline Vineyards & 18.99 & 30.56 & 27.67 & 30.56 & 29.44 \\
Olive groves & 22.21 & 29.68 & 29.15 & 29.68 & 27.44 \\
Orchards (excl. citrus, nuts) & 11.66 & 21.77 & 17.28 & 21.77 & 12.51 \\
Citrus fruits & 7.12 & 25.48 & 18.38 & 25.48 & 25.48 \\
Nuts & 33.43 & 66.86 & 47.76 & 66.86 & 35.94 \\
\hline
\end{tabular}

(3) Produce agro-pellets from APPR for market

Agro-pellets are considered of lower quality than the wood pellets which is reflected in the lower market price. If reaching $90 \%$ of the wood pellet price of 250 euro $\cdot t^{-1}$ [39], only EU-28 plantations with an average of $>92$ ha ( $>222$ ha for nuts) could consider such a venture to achieve PB in a year. 
Wood pellet prices in Croatia are lower than those of the international market prices ( $238 \mathrm{euro} \cdot \mathrm{t}^{-1}$ in 2019 [46-48] but APPR yields per hectare are closer to the EU-28 maximum values for fruit and nuts plantations, which brings the average size of the perennial crop plantation suitable to consider an agro-pellet production to the similar size to the EU-28 average but starting from 40 ha of orchards.

The minimum agro-pellet production to have a pay-back period of 5 years would be $21-22 \mathrm{t} \cdot \mathrm{y}^{-1}$ which is equivalent to the average size of 18.07 and 15.22 ha (44 and 22.58 ha for nuts) for the EU-28 average and Croatia, respectively (Table 11).

Table 11. Average sizes of perennial crop plantations for agro-pellet production, EU-28 averages and Croatian average.

\begin{tabular}{cccccc}
\hline Perennial Plantation & EU-28 Min & EU-28 Max & EU-28 Mean & EU-28 Mode & HR Average \\
\hline Vineyards & 13.02 & 20.95 & 18.97 & 20.95 & 19.27 \\
Olive groves & 14.97 & 20.00 & 19.64 & 20.00 & 17.65 \\
Orchards (excl. citrus, nuts) & 7.86 & 14.67 & 11.64 & 14.67 & 8.05 \\
Citrus fruits & 4.66 & 16.67 & 12.02 & 16.67 & 15.91 \\
Nuts & 22.00 & 44.00 & 31.43 & 44.00 & 22.58 \\
\hline
\end{tabular}

\section{(4) Selling APPR chips on the market}

This option could be perceived as the least value-added option for the APPR owner and is equal to or less than the wood chips purchasing price at the biomass market that is mostly attached to chipped large, bulk quantities. Solid biomass market for wood chips is still not as mature as the pellet market which generates an opportunity in the local markets that could have high local prices for wood chips. Only in Lithuania, the price span is $139.97-185$ euro $t^{-1}$ [47]. In Croatia, the price of wood chips is about 75-111.26 euro $\cdot \mathrm{t}^{-1}[39,41,48]$. Depending on the investment needed in the alternatives, APPR quantity, wood chips market maturity, and negotiation skills, selling APPR as wood chips might surface as the most lucrative option. There are two business models considered: small holdings ( $<5 \mathrm{ha})$ with a production of $1 \mathrm{t} \cdot \mathrm{y}^{-1}$ and larger holdings ( $>5 \mathrm{ha}$ ) with minimum production of $10 \mathrm{t} \cdot \mathrm{y}^{-1}$.

From the described business models for APPR, the current investment environment in Croatia supports direct combustion of APPR either as fuel switching or fuel supplement, producing agro-pellets, and selling APPR as chips to the market. The business model that includes micro-grids and involves more than one household in energy consumption remains a challenge for the Croatian countryside. The business models for the energy utilization of APPR are ranked by attractiveness (PB and triple challenge fit) for APPR owners in Croatia in Table 12. Details on PB period calculations for each of the business models are in the Appendix A.

\subsection{Sizing the Replication Rate}

According to the Farm Register of the Agency for Payment in Agriculture, Fishery and Rural Development, there were 167,676 agricultural holdings in Croatia at the end of 2018 (Table 13). The structure of Croatian perennial crop plantations under analysis is shown in Table 14. The structure of perennial crops and farm size indicate that the shortest business models-fuel supplement or fuel switching and chip production for the market-could be the most suitable options for Croatian rural areas. The latest and the only publicly available data on perennial crop plantations stratification by size, location, and fruit are available from the Agriculture Census in 2003 [49] which is now obsolete. For that reason, the total area of perennial crop plantation by type was reduced by $90 \%$ assuming a similar structure of perennial crops with the structure of Croatian agriculture holdings (Table 13). Contrasting area size needed to cover space heating demand in both Continental and Mediterranean parts of Croatia, it would be feasible to have a large replication rate (Table 14): 12,000 and 26,800 perennial crop plantations for Continental and Mediterranean Croatia, respectively, which is $3 \%$ and $12 \%$, respectively, of the total households of those two NUTS-02 areas. 
Table 12. Ranking of the attractiveness of APPR business models for Croatia.

\begin{tabular}{|c|c|c|c|c|}
\hline Rank & Business Model & $\begin{array}{l}\text { Investment } \\
\text { (Euro) }\end{array}$ & $\begin{array}{l}\text { Savings/Income } \\
\left(\text { Euro } \cdot y^{-1}\right)\end{array}$ & $\begin{array}{c}\text { PB } \\
\text { (year) }\end{array}$ \\
\hline & Fuel supplement & & & \\
\hline \multirow[t]{2}{*}{1} & HR04 & \multirow[t]{2}{*}{ No } & \multirow{2}{*}{\multicolumn{2}{|c|}{$\begin{array}{c}1288-1367 \\
613-651\end{array}$}} \\
\hline & HR03 & & & \\
\hline 2 & APPR as chips-holding $>5$ ha & 1000 & 750 & 1.3 \\
\hline \multirow[t]{2}{*}{3} & APPR as chips-holding $<5$ ha & \multirow[t]{2}{*}{250} & \multirow[t]{2}{*}{75} & \multirow[t]{2}{*}{3.3} \\
\hline & Fuel switching: Electricity-white tariff & & & \\
\hline \multirow[t]{3}{*}{4} & HR04 & \multirow[t]{2}{*}{4730} & 2231 & 2.1 \\
\hline & HR03 & & 1062 & 4.5 \\
\hline & Fuel switching Electricity-blue tariff & & & \\
\hline \multirow[t]{2}{*}{5} & HR04 & \multirow[t]{2}{*}{4730} & 2043 & 2.3 \\
\hline & HR03 & & 972 & 4.9 \\
\hline \multirow[t]{2}{*}{6} & Agro-pellet production & \multirow[t]{2}{*}{25,500} & \multirow[t]{2}{*}{5214} & \multirow[t]{2}{*}{4.9} \\
\hline & Fuel switching Electricity-red tariff & & & \\
\hline \multirow[t]{3}{*}{7} & HR04 & \multirow[t]{2}{*}{4730} & 1855 & 2.5 \\
\hline & HR03 & & 883 & 5.4 \\
\hline & Fuel switching light heating oil & \multirow{3}{*}{4730} & & \\
\hline \multirow[t]{3}{*}{8} & HR04 & & 1409 & 3.9 \\
\hline & HR03 & & 671 & 7.1 \\
\hline & Fuel switching LPG butane & & & \\
\hline \multirow[t]{3}{*}{9} & HR04 & \multirow{2}{*}{4730} & 1265 & 3.7 \\
\hline & HR03 & & 602 & 7.9 \\
\hline & Fuel switching LPG propane butane & & & \\
\hline \multirow[t]{2}{*}{10} & HR04 & \multirow[t]{2}{*}{4730} & 1220 & 3.9 \\
\hline & HR03 & & 581 & 8.1 \\
\hline 11 & A $50 \mathrm{~kW} \mathrm{CHP} \mathrm{unit}$ & $>235,500$ & $5959-20,932$ & $>11.3$ \\
\hline
\end{tabular}

Table 13. The structure of Croatian agriculture holdings [50].

\begin{tabular}{ccc}
\hline Size of the Farm (ha) & Number of Farms & Share in Total Farm (\%) \\
\hline No land under utilization & 11,234 & 6.7 \\
$<4.99$ & 119,385 & 71.2 \\
$5-19.99$ & 27,834 & 16.6 \\
$>20$ & 9222 & 5.5 \\
\hline
\end{tabular}

Table 14. The structure of Croatian perennial crop plantations (calculations based on references [50,51]) and possible replication rate for fuel supplement or fuel switching for space heating on APPR for Croatia.

\begin{tabular}{cccc}
\hline Perennial Crop Plantation & Area (ha) & HR04 (No. of Replications) & HR03 (No. of Replications) \\
\hline Orchards (excl. citrus, nuts) & 15,457 & 7765 & 6992 \\
Citrus fruit & 2260 & & 1673 \\
Nuts & 9612 & 2041 & 757 \\
Vineyards & 23,629 & 3603 & 7569 \\
Olive groves & 18,656 & & 12,825 \\
\hline
\end{tabular}

Note: assuming locations HR04:HR03 as following: 50:50 vineyards, 85:15 nuts plantations 70:30 fruit production.

\subsection{Estimating Effects at the Micro Level}

A Croatian household with a $>1$ ha orchard, vineyard, or olive grove would save 1300 and 630 euro per heating season if supplementing wood with APPR in HR04 and HR03, respectively. That would be about 105 (HR04) to 220 (HR03) euro per month savings from heating fuel expenses. Based on the household structure, about 200,000 (HR04) and 185,000 (HR03) households could benefit from fuel supplement. 
In the case of fuel switching, excluding the investment costs, a household would achieve the highest savings when switching from electricity: about 2000 (HR04) and 1000 (HR03) euro per heating season (Table 15) per household. Given the heating fuel structure, fuel switching is more likely to occur on the coast (HR03) with a potential of 15,500 households.

Table 15. Average annual savings of fuel switching with APPR by fuel type per heating season for Continental (HR04) and Adriatic (HR03) Croatia, in euro.

\begin{tabular}{ccc}
\hline Fuel & HR04 & HR03 \\
\hline electricity-blue & 2043 & 972 \\
electricity-white & 2231 & 1062 \\
electricity-red & 1855 & 883 \\
electricity-black & 986 & 469 \\
light heating oil & 1409 & 671 \\
LPG-propane butane & 1220 & 581 \\
LPG-butane & 1265 & 602 \\
pellets & 1137 & 541 \\
natural gas & 859 & 409 \\
briquettes & 881 & 419 \\
fuel wood-public & 1030 & 490 \\
fuel wood-private & 1094 & 521 \\
\hline
\end{tabular}

A fruit producer, olive grower, or vineyard owner could participate in the biofuel market as either APPR pellet or chip producers. Applying the same size structure as for the total Croatian agricultural holdings (Table 12), a potential replication rate would be 1177 candidates for agro-pellets (Table 16). Wood chip production is assumed at a professional level with participation in the market with $>10 \mathrm{t} \cdot \mathrm{y}^{-1}$. The potential replication rate of such perennial crop plantations would be 9457 (Table 16).

Table 16. Potential replication rate for producing agro-pellets and chips from APPR in Croatia.

\begin{tabular}{ccccc}
\hline \multirow{2}{*}{ Perennial Crop Plantation } & \multicolumn{2}{c}{ Agro-Pellets } & \multicolumn{2}{c}{ APPR Chips } \\
& HR04 & HR03 & HR04 & HR03 \\
\hline Vineyards & 196 & 412 & 788 & 1656 \\
Olive groves & 0 & 698 & 0 & 2806 \\
Orchards (excl. citrus, nuts) & 423 & 381 & 1699 & 1530 \\
Citrus fruits & 0 & 91 & 0 & 366 \\
Nuts & 111 & 41 & 446 & 166 \\
\hline
\end{tabular}

The minimum additional income from sales is calculated based on the minimum size of both pellet $\left(22 \mathrm{t} \cdot \mathrm{y}^{-1}\right)$ and chip $\left(10 \mathrm{t} \cdot \mathrm{y}^{-1}\right)$ quantity. On the top of the primary production, annual income from sales of APPR as agro-pellets would be about 5200 euro and as APPR chips about 600 euro per holding.

Average disposable income per household was 11,700 euro in 2016, while average equivalized disposable income amounted to 6400 euro [52,53] which indicates an option for APPR use as an energy poverty alleviation measure.

\subsection{Estimating Effects at the Macro Level}

The effects of utilization of APPR as solid biofuel on VAT generation in Croatia was calculated by multiplying the micro effects and adding $25 \%$ of VAT to the turnover (Table 17 ).

If APPR is to replace electricity heating in rural households, it would reduce $27,050 \mathrm{tCO}_{2 \mathrm{eq}} \cdot \mathrm{y}^{-1}$ which is $0.2 \%$ of the total emissions of $\mathrm{CO}_{2 \mathrm{eq}}$ from the energy sector.

Additional demand for machinery related to domestic production capacities is existing for heating systems. There are national capacities to produce pellet lines and chippers but that production is to be established. 
Table 17. Estimated effect on VAT generation when considering APPR as solid biofuel in Croatia.

\begin{tabular}{|c|c|c|c|c|c|}
\hline & \multirow{2}{*}{ Business Model } & \multirow{2}{*}{$\begin{array}{l}\text { Replication Rate } \\
\text { (In 1000) }\end{array}$} & \multicolumn{3}{|c|}{ VAT (In 1000,000 Euro) } \\
\hline & & & Single Time & New Source & Lost Source \\
\hline \multicolumn{6}{|c|}{ Fuel replacement } \\
\hline \multirow[t]{2}{*}{1} & HR04 & 12 & & & 3.93 \\
\hline & HR03 & 27 & & & 4.16 \\
\hline \multirow{3}{*}{2} & Fuel & & & & \\
\hline & switching-electricity & 16 & & & 4.13 \\
\hline & $\begin{array}{l}\text { Heating system } \\
\text { adjustments }\end{array}$ & & 18.40 & & \\
\hline \multirow{2}{*}{3} & Pellet production & 2 & & 12.27 & \\
\hline & Pellet line & & 15.30 & & \\
\hline \multirow[b]{2}{*}{4} & Chip production & 9 & & 5.62 & \\
\hline & Chipper & & 2.36 & & \\
\hline
\end{tabular}

\section{Conclusions}

The paper sheds a light on the socio-economic role of APPR use as a solid biofuel. The paper suggests business models that could either alleviate energy poverty in rural areas or increase the competitiveness of perennial fruit and olive growers and vineyard owners. The effects of mobilizing APPR potential via business models are estimated at the micro (households' income) and macro (number of households affected, size of the investment, tax effect, $\mathrm{CO}_{2 \mathrm{eq}}$ savings) levels in Croatia.

The proposed approach to integrate APPR into local energy planning indicated that the traditional approach undermines the APPR energy potential as a sustainable and readily available solid biofuel. From a negligible $(0.33 \%)$ share in the total EU-28 primary energy demand, APPR energy potential found its place in final energy demand for rural households where it can make $5 \%$ and $4 \%$ difference at the EU-28 level and Croatia, respectively. With a more precise allocation of APPR supply with the local end-use energy demand in rural households, the value of APPR energy potential is better matched than with the aggregated national end-use energydemand.

Just in the case of two regions in Croatia with different climatic zones: Continental (HR04) and Mediterranean (HR03), the threshold sizes of perennial plots to be included in energy planning vary. A household located on the Adriatic coast would consume $57 \%$ of energy $\left(48.53 \mathrm{GJ} \cdot \mathrm{y}^{-1}\right.$ ) of its Continental $\left(85.05 \mathrm{GJ} \cdot \mathrm{y}^{-1}\right)$ counterpart. The difference in the final energy consumption pattern is reflected in the thermal end-use (space heating, water heating, and cooking). The difference in energy demand between the regions is linked with the average size of a perennial crop plantation to meet the space heating demand for the Mediterranean and Continental household. With a closer look, APPR from fruit orchards with $<1$ ha size and located on the Croatian coast are also suitable to meet the space heating consumption of local households.

When considering utilization of APPR for simultaneous production of electricity and heat, even for a micro-CHP unit, larger plots of $>7$ ha are necessary. A $50 \mathrm{kWh} \mathrm{CHP} \mathrm{unit} \mathrm{would} \mathrm{cover} \mathrm{electricity}$ demand for about 20 households in both the EU-28 (average) and Croatia. However, the span of EU-28 household electricity consumption is rather wide from 1000 to 5000 depending on the country's level of development and geographical position. In the absence of a legal framework to support the development of micro-grids, an APPR owner could opt for supplying a filling station to power e-vehicles. Generated electricity would support about a third of the annual demand for fuel for an average distance traveled by car in Croatia. Yet, all business models related to CHP demonstrated the least attractive PB period (all beyond 10 years) and were too complex to implement without a clear policy framework. It is our belief that the CHP powered by APPR is the option to be supported with rural development measures as a smart village evolution and micro-grids.

Selling APPR either as agro-pellets or chips indicated economic feasibility without supporting measures in terms of financing, although biomass market maturity would define the attractiveness of these business models. 
In Croatia, encouraging utilization of APPR could be considered an energy poverty alleviation measure. Over $10 \%$ of household income in $63 \%$ of Croatian households is spent on energy which is considered an indicator of energy poverty. A Croatian household with an orchard, vineyard, or olive grove would save 1300 and 630 euro per heating season if supplementing wood with APPR in HR04 and HR03, respectively; they would see 105-220 euro monthly savings from heating and $5 \%-11 \%$ of disposable income saved. In Croatia, $28.5 \%$ of households are at risk of poverty or social exclusion, with $24 \%$ and $30.8 \%$ in Adriatic and Continental Croatia, respectively. In the EU-28 and Croatia, $7.3 \%$ and $7.7 \%$, respectively, were unable to keep the home adequately warm. The share of such households was the highest in Bulgaria $(33.7 \%)$, then Lithuania $(27.9 \%)$ but highly present within the Mediterranean countries (Greece: $22.7 \%$, Portugal: $19.6 \%$, Italy: 14.1\%). With APPR as a supplement to wood heating in individual stoves, some 49 million euro could be available for the Croatian rural community for different spending than for fuel.

Given the structure of space heating in Croatia, APPR could be used as a fuel-saving option in the continental households (aggregated savings of 16 million euro $\cdot \mathrm{y}^{-1}$ ) and as fuel-switching option at the coast (aggregated savings of 16.5 million euro $\cdot \mathrm{y}^{-1}$ for switching from heating with electricity). Namely, the presence of district heating, a well-developed natural gas grid, and a dominant share of fuelwood for space heating make fuel-switching options not competitive to the existing heating options in the continental area. On the Croatian coast, both fuel supplement and fuel-switching options are attractive as $6 \%$ households heat with electricity, peaking with $13 \%-14 \%$ at Dubrovnik-Neretva and Split-Dalmatia counties. At the full potential of APPR for fuel switching and fuel supplementing, a loss of VAT of 12.23 million euro is generated.

On the other hand, if APPR placed on the market as solid biofuels—pellets and chips-VAT will generate 17.7 million euro of one-time investments and 17.9 million euro $\cdot \mathrm{y}^{-1}$ from annual sales at full APPR potential and current prices.

Although GHG emissions savings are not impressive for Croatia from the fuel switching, this could be a different case for countries with significant fruit production and fossil energy share either in heating or electricity generation mix (e.g. Poland).

The outcomes of this paper give solid indications of which way to direct rural development and clean energy policy in terms of APPR energy potential deployment. The following steps would be developing business models in more detail (operational and maintenance costs) and ranking them not only by financial indicators but also by the perceptions of the rural communities.

Author Contributions: Conceptualization, B.K., M.N., and T.R.; methodology, B.K. and M.N.; validation, M.N. and T.R.; formal analysis, B.K.; investigation, T.R. and M.N.; data curation, T.R. and M.N.; writing-original draft preparation, B.K. and M.N.; writing-review and editing, M.N. and T.R. All authors have read and agreed to the published version of the manuscript.

Funding: This research received no external funding but it represents a follow-up of the work invested in the European Union's Horizon 2020 research and innovation programme under grant agreement No 691748: uP_running: "Take-off for sustainable supply of woody biomass from agrarian pruning and plantation removal".

Acknowledgments: We express sincere gratitude to the uP_running project which inspired us for this paper and whose data and analysis support our results. We would like to acknowledge the effort and suggestions from the reviewers and William White from Kingsmere Economics Consulting, Edmonton, Canada, for proofreading and English language corrections.

Conflicts of Interest: The authors declare no conflict of interest. The funders had no role in the design of the study; in the collection, analyses, or interpretation of data; in the writing of the manuscript; or in the decision to publish the results.

\section{Appendix A}

Detailed computations of the business models evaluated using the pay-back (PB) period for Croatia:

(1) Use APPR in direct combustion to generate heat

Fuel supplement option: no investment needed, savings for the household space heating equivalent to wood logs prices (private or/and public wood). 
Table A1. APPR as fuel supplement option for Continental (HR04) and Mediterranean (HR03) household (in euro $\cdot y^{-1}$ ).

\begin{tabular}{cccc}
\hline \multicolumn{2}{c}{ HR04 } & \multicolumn{2}{c}{ HR03 } \\
Savings-Public Wood & Savings_Private Wood & Savings_Public Wood & Savings_Private Wood \\
\hline 1288 & 1367 & 613 & 651 \\
\hline
\end{tabular}

Fuel-switching option: investment of 4730 euro needed for heating system adaptations, savings for the household space heating equivalent to the fuels' prices higher than wood logs.

Table A2. APPR as fuel-switching option: savings per year for fuel and pay-back (PB) by fuel type.

\begin{tabular}{|c|c|c|c|c|}
\hline Fuel Type & $\begin{array}{c}\text { HR04 } \\
\left(\text { Euro }^{-1}\right)\end{array}$ & $\begin{array}{c}\text { HR03 } \\
\left(\text { Euro }^{-1}\right)\end{array}$ & $\begin{array}{c}\text { PB_HR04 } \\
\text { (y) }\end{array}$ & $\begin{array}{c}\text { PB_HR03 } \\
(y)\end{array}$ \\
\hline electricity-blue & 2043 & 972 & 2.3 & 4.9 \\
\hline electricity-white & 2231 & 1062 & 2.1 & 4.5 \\
\hline electricity-red & 1855 & 883 & 2.5 & 5.4 \\
\hline electricity-black & 986 & 469 & 4.8 & 10.1 \\
\hline light heating oil & 1409 & 671 & 3.4 & 7.1 \\
\hline LPG-propane butane & 1220 & 581 & 3.9 & 8.1 \\
\hline LPG-butane & 1265 & 602 & 3.7 & 7.9 \\
\hline natural gas & 859 & 409 & 5.5 & 11.6 \\
\hline
\end{tabular}

(2) Direct combustion of APPR to generate both heat and electricity in a CHP plant

Investment to a $50 \mathrm{~kW}$ unit: 4700 euro/kW for CHP plant and $2 \times 2500 \mathrm{~W}$ home chippers at 250 euro each. Total investment: 235,500 euro. Additional costs for heating system adaptations per household: 4730 euro.

Table A3. APPR to cover electricity consumption of households with fuel switching in Croatia.

\begin{tabular}{|c|c|c|c|c|c|}
\hline \multirow{2}{*}{\multicolumn{2}{|c|}{$\begin{array}{l}\text { Electricity Savings } \\
\left(\text { Euro } \cdot y^{-1}\right)\end{array}$}} & \multicolumn{2}{|c|}{ Heat Savings } & \multirow{2}{*}{$\begin{array}{c}\text { Total } \\
\left(\text { Euro }^{-1} \mathbf{y}^{-1}\right)\end{array}$} & \multirow{2}{*}{$\begin{array}{l}\text { PB } \\
(y)\end{array}$} \\
\hline & & Fuel Type & $\left(\right.$ Euro $\left.\cdot y^{-1}\right)$ & & \\
\hline \multirow[t]{9}{*}{ Average savings } & 4606 & & & & \\
\hline & & electricity-blue & 7054 & 11,660 & 28.31 \\
\hline & & electricity—white & 7703 & 12,309 & 26.82 \\
\hline & & electricity-red & 6405 & 11,012 & 29.98 \\
\hline & & electricity-black & 3405 & 8012 & 41.20 \\
\hline & & light heating oil & 11,906 & 16,512 & 19.99 \\
\hline & & LPG-propane butane & 12,905 & 17,511 & 18.85 \\
\hline & & LPG-butane & 11,595 & 16,201 & 20.37 \\
\hline & & natural gas & 7709 & 12,316 & 26.80 \\
\hline
\end{tabular}

Fuel-switching option: all produced electricity is used at the households meeting total needs of household for all end-use consumption. Both heat and electricity production surpass individual household demand which requires a micro-grid system.

Table A4. APPR to cover all end-use needs of a household in Croatia.

\begin{tabular}{|c|c|c|c|c|}
\hline Tariff Model & $\begin{array}{l}\text { Electricity Savings } \\
\left(\text { Euro } \cdot y^{-1}\right)\end{array}$ & $\begin{array}{l}\text { Heat Savings } \\
\left(\text { Euro } \cdot y^{-1}\right)\end{array}$ & $\begin{array}{l}\text { Savings Total } \\
\left(\text { Euro } \cdot y^{-1}\right)\end{array}$ & $\begin{array}{l}\text { PB } \\
(\cdot y)\end{array}$ \\
\hline electricity-blue & 5290 & 7054 & 12,345 & 19.1 \\
\hline electricity-white & 5777 & 7703 & 13,480 & 17.5 \\
\hline electricity-red & 4804 & 6405 & 11,209 & 21.0 \\
\hline electricity-black & 2554 & 3405 & 5959 & 39.5 \\
\hline
\end{tabular}


Fuel-switching option for heating with sales of electricity at a privileged renewable electricity price. Heating supply surpasses individual household demand which requires a micro-district heating system or on-farm heating demand. Privileged price set at 17.84 eurocents $\mathrm{kWh}^{-1}$. Investment in central heating system not needed.

Table A5. APPR to cover heating of a household in Croatia with sales of electricity to the grid at privileged price and fuel-switching savings.

\begin{tabular}{|c|c|c|c|c|}
\hline Fuel Switched & $\begin{array}{l}\text { Electricity Sales } \\
\left(\text { Euro } \cdot y^{-1}\right)\end{array}$ & $\begin{array}{l}\text { Heat Savings } \\
\left(\text { Euro }^{-1}\right)^{-1}\end{array}$ & $\begin{array}{c}\text { Sales + Savings Total } \\
\left(\text { Euro } \cdot y^{-1}\right)\end{array}$ & $\begin{array}{l}\text { PB } \\
(y)\end{array}$ \\
\hline & 8027 & & & \\
\hline light heating oil & & 11,906 & 19,933 & 11.8 \\
\hline LPG-propane butane & & 12,905 & 20,932 & 11.3 \\
\hline LPG-butane & & 11,595 & 19,622 & 12.0 \\
\hline natural gas & & 7709 & 15,736 & 15.0 \\
\hline
\end{tabular}

Fuel-switching option for heating with establishing an electric vehicle filling station. Additional investment for a $50 \mathrm{~kW}$ fast charging station: 20,000 euro. Price of base electricity at the CROPEX exchange rate: 36.13 euro· $\mathrm{MWh}^{-1}$.

Table A6. APPR to cover heating of a household in Croatia with sales of electricity at charging station and fuel-switching savings.

\begin{tabular}{|c|c|c|c|c|}
\hline Fuel Switched & $\begin{array}{l}\text { Electricity Charging } \\
\left(\text { Euro } \cdot y^{-1}\right)\end{array}$ & $\begin{array}{l}\text { Heat Savings } \\
\left(\text { Euro } \cdot \mathbf{y}^{-1}\right)\end{array}$ & $\begin{array}{c}\text { Sales+Savings Total } \\
\left(\text { Euro } \cdot y^{-1}\right)\end{array}$ & $\begin{array}{l}\text { PB } \\
(y)\end{array}$ \\
\hline & 1626 & & & \\
\hline light heating oil & & 11,906 & 13,532 & 18.9 \\
\hline LPG-propane butane & & 12,905 & 14,531 & 17.6 \\
\hline LPG-butane & & 11,595 & 13,220 & 19.3 \\
\hline natural gas & & 7709 & 9335 & 27.4 \\
\hline
\end{tabular}

(3) Produce agro-pellets from APPR for market

Investment in a $500 \mathrm{~kg} \mathrm{~h}^{-1}$ pellet production line: 25,000 euro. Investment in a tractor attached chipper, with the ability to chip APPR with $<127 \mathrm{~mm}$ diameter at $6-7 \mathrm{~m}^{3} \cdot \mathrm{h}^{-1}$ : 1000 euro. Total investment: 26,000 euro. To achieve a 5-year PB to pay off the investment in the pellet line at 105 euro $\cdot t^{-1}, 22 \mathrm{t}$ of agro-pellets from pruning must be produced.

(4) Selling APPR as chips

Holdings with $<5$ ha: Investment in a $2500 \mathrm{~W}$ wood chipper, with the ability to chip APPR with $<45 \mathrm{~mm}$ diameter: 250 euro. PB at 3.33 years.

Holdings with $>5$ ha: Investment in a tractor attached chipper, with the ability to chip APPR with $<127 \mathrm{~mm}$ diameter at $6-7 \mathrm{~m}^{3} \cdot \mathrm{h}^{-1}: 1000$ euro. $\mathrm{PB}$ at 1.33 year.

\section{References}

1. Bentsen, N.S.; Felby, C. Biomass for energy in the European Union-A review of bioenergy resource assessments. Biotechnol. Biofuels 2012, 5, 25. [CrossRef] [PubMed]

2. Panoutsou, C.; Eleftheriadis, J.; Nikolaou, A. Biomass supply in EU27 from 2010 to 2030. Energy Policy 2009, 37, 5675-5686. [CrossRef]

3. Monforti, F.; Bódis, K.; Scarlat, N.; Dallemand, J.-F. The possible contribution of agricultural crop residues to renewable energy targets in Europe: A spatially explicit study. Renew. Sustain. Energy Rev. 2013, 19, 666-677. [CrossRef] 
4. Bai, A.; Durkó, E.; Tar, K.; Tóth, J.B.; Lázár, I.; Kapocska, J.; Kircsi, A.; Bartók, B.; Vass, R.; Pénzes, J.; et al. Social and economic possibilities for the energy utilization of fitomass in the valley of the river Hernád. Renew. Energy 2016, 85, 777-789. [CrossRef]

5. Kulisic, B.; Par, V.; Metzler, R. Calculation of on-farm biogas potential: A Croatian case study. Biomass Bioenergy 2015, 74, 66-78. [CrossRef]

6. Scarlat, N.; Fahl, F.; Dallemand, J.-F.; Monforti-Ferrario, F.; Motola, V. A spatial analysis of biogas potential from manure in Europe. Renew. Sustain. Energy Rev. 2018, 94, 915-930. [CrossRef]

7. Duca, D.; Toscano, G.; Pizz, A.; Rossini, G.; Fabrizi, S.; Lusecoli, G.; Servili, A.; Mancini, V.; Romanazzi, G.; Mengarelli, C. Evaluation of the Characteristics of Vineyard Pruning Residues for Energy Applications: Effect of Different Copper-Based Treatments. J. Agric. Eng. 2016. [CrossRef]

8. Elbersen, B.; Startisky, I.; Hengeveld, G.; Schelhaas, M.-J.; Naeff, H.; Böttcher, H. Atlas of EU Biomass Potentials: Spatially Detailed and Quantified Overview of EU Biomass Potential Taking into Account the Main Criteria Determining Biomass Availability from Different Sources. Deliverable 3.3; Biomass Futures Project; Alterra/IIASA (IEE 08653 S12.529 241 3.3): Wageningen, The Netherlands, 2012.

9. European Commission under the 7th Framework Programme for Research, Technological Development and Demonstration under Grant Agreement No. FP7-608622: S2Biom “Delivery of Sustainable Supply of Non-Food Biomass to Support a "Resource-Efficient" Bioeconomy in Europe" (2013-2016). Available online: https://www.s2biom.eu/en/ (accessed on 15 November 2019).

10. European Union's Horizon 2020 Research and Innovation Programme under Grant Agreement No. 691748: Up_Running: “Take-Off for Sustainable Supply of Woody Biomass from Agrarian Pruning and Plantation Removal" (2017-2019). Available online: https://www.up-running.eu (accessed on 23 November 2019).

11. Dyjakon, A.; García-Galindo, D. Implementing Agricultural Pruning to Energy in Europe: Technical, Economic and Implementation Potentials. Energies 2019, 12, 1513. [CrossRef]

12. Toscano, G.; Alfano, V.; Scarfone, A.; Pari, L. Pelleting Vineyard Pruning at Low Cost with a Mobile Technology. Energies 2018, 11, 2477. [CrossRef]

13. Bilandžija, N.; Voća, N.; Krička, T.; Martin, A.; Jurišić, V. Energy potential of fruit tree pruned biomass in Croatia. Span. J. Agric. Res. 2012, 2, 292-298. [CrossRef]

14. Romero-García, J.M.; Sanchez, A.; Rendón-Acosta, G.; Martínez-Patiño, J.C.; Ruiz, E.; Magaña, G.; Castro, E. An Olive Tree Pruning Biorefinery for Co-Producing High Value-Added Bioproducts and Biofuels: Economic and Energy Efficiency Analysis. Bioenergy Res. 2016, 9, 1070-1086. [CrossRef]

15. Spinelli, R.; Picchi, G. Industrial harvesting of olive tree pruning residue for energy biomass. Bioresour. Technol. 2010, 101, 730-735. [CrossRef] [PubMed]

16. EUROSTAT: Energy Balance Sheets 2017 Data, 2019 Edition. Available online: https://ec.europa.eu/eurostat/ documents/3217494/10077623/KS-EN-19-001-EN-N.pdf/59b44e6f-ff33-488b-a85f-9c4f60703afc (accessed on 16 August 2019).

17. EUROSTAT. Energy Consumption in Households. Available online: https://ec.europa.eu/eurostat/statisticsexplained/index.php/Energy_consumption_in_households\#Energy_consumption_in_households_by_ type_of_end-use (accessed on 28 October 2019).

18. Eurostat Statistics Explained. Statistics on Rural Areas in the EU. Available online: https://ec.europa.eu/ eurostat/statistics-explained/index.php/Statistics_on_rural_areas_in_the_EU (accessed on 27 June 2018).

19. ODYSSEE MURE Database. Available online: https://www.odyssee-mure.eu/publications/efficiency-bysector/households/heating-consumption-per-m2.html (accessed on 19 November 2019).

20. EUROSTAT. Final Consumption Expenditure of Households by Consumption Purpose (COICOP 3 Digit (20-12-2019). Available online: https://appsso.eurostat.ec.europa.eu/nui/submitViewTableAction.do (accessed on 16 August 2019).

21. Ostenwalder, A.; Pigneur, Y. Business Model generation: A Handbook for Visionaries, Game Changers and Challengers; Wiley and Sons: Hoboken, NJ, USA, 2010.

22. Lewandowski, M. Designing the Business Models for Circular Economy-Towards the Conceptual Framework. Sustainability 2016, 8, 43. [CrossRef]

23. Chanwoo, C.; Sungjoo, L. How Firms Can Get Ideas from Users for Sustainable Business Innovation. Sustainability 2015, 7, 16039-16059. [CrossRef]

24. uP_running. uP_running Demonstration Case Studies Analysis; Deliverable Report D3.3, uP_running Project (H2020-691748); CIRCE: Zaragoza, Spain, 2019. 
25. uP_running. Flagship Success Cases Update v1; Deliverable Report D6.3, uP_running Project (H2020 691748); CIRCE: Zaragoza, Spain, 2017.

26. uP_running. Flagship Success Cases Update v2; Deliverable Report D6.3, uP_running Project (H2020 691748); CIRCE: Zaragoza, Spain, 2019.

27. uP_running: Take-Off for Sustainable Supply of Woody Biomass from Agrarian Pruning and Plantation Removal (from April 2016 to June 2019). This Project Has Received Funding from the European Union's Horizon 2020 Research and Innovation Programme under Grant Agreement No. 691748. Available online: https://www.up-running.eu (accessed on 22 November 2019).

28. Sivertsson, O.; Tell, J. Barriers to Business Model Innovation in Swedish Agriculture. Sustainability 2015, 7, 1957-1969. [CrossRef]

29. Cichy, W.; Witczak, M.; Walkowiak, M. Fuel properties of woody biomass from pruning operations in fruit orchards. BioResources 2017, 12, 6458-6470. [CrossRef]

30. Borja Velázquez-Martí, B.; Isabel López-Cortés, I.; Domingo Salazar- Hernández, D.; Ángel Jesús Callejón-Ferre, A. Modeling the Calorific Value of Biomass from Fruit Trees Using Elemental Analysis Data. Biomass Vol. Estim. Valorization Energy 2017, 271. [CrossRef]

31. Energy Institute Hrvoje Pozar (EIHP). Methodology for Implementation of Energy Audit in Buildings; EIHP: Zagreb, Croatia, 2017. (In Croatian)

32. UNDP. Energy in Your Home_Live with More Quality and Pay Less; Promoting Energy Efficiency in Croatia Project; UNDP: New York, NY, USA, 2013. (In Croatian)

33. García-Galindo, D.; Dyjakon, A.; Cay Villa-Ceballos, F. Building Variable Productivity Ratios for Improving Large Scale Spatially Explicit Pruning Biomass Assessments. Energies 2019, 12, 957. [CrossRef]

34. Hancher, L.; Winters, B.M. The EU Winter Package_Briefing Paper; Allen \& Overy: London, UK, February 2017.

35. EUROSTAT. Income and Living Conditions. Inability to Keep Home Adequately Warm-EU-SILC Survey. Available online: http://appsso.eurostat.ec.europa.eu/nui/setupDownloads.do (accessed on 17 December 2019).

36. ODYSSEE-MURE DATABASES Sectoral Profile-Transport. Available online: https://www.odyssee-mure. eu/publications/efficiency-by-sector/transport/distance-travelled-by-car.html (accessed on 2 April 2020).

37. European Environment Agency. Overview of Electricity Production and Use in Europe. Prod-ID: IND-353-en also Known as: ENER 038. Created 13 Nov 2017 Published 18 Dec 2018 Last Modified 29 Apr 2019. Available online: https://www.eea.europa.eu/data-and-maps/indicators/overview-of-the-electricity-production-2/ assessment-4 (accessed on 16 August 2019).

38. HEP plin. Cijene plina za kućanstva. Available online: https://www.hep.hr/plin/cijene-plina-i-usluga/cijeneplina/cijene-plina-za-kucanstva/1620 (accessed on 16 August 2019).

39. Njuškalo. Available online: www.njuškalo.hr (accessed on 16 August 2019).

40. HEP Elektra. Cijene za kućanstva. Available online: http://www.hep.hr/elektra/kucanstvo/tarifne-stavkecijene/1547 (accessed on 1 January 2019).

41. Hrvatske šume. Cjenik glavnih šumskih proizvoda. 2018. Available online: https://www.hrsume.hr/images/ dok/proizvodi/cjenik_glavnih_sumskih_proizvoda_201804.pdf (accessed on 17 April 2018).

42. Energy Institute Hrvoje Pozar. Ministry of Environment and Energy of the Republic of Croatia: Energy in Croatia, Annual Energy Report 2018; Energy Institute Hrvoje Pozar: Zagreb, Croatia, 2019.

43. Croatian Bureau of Statistics. Data on Energy Efficiency in Households and Services. Available online: https://www.dzs.hr/Hrv_Eng/Other/Podaci\%20o\%20energetskoj\%20ucinkovitosti\%20u\% 20kucanstvima\%20i\%20uslugama\%20u\%202012.pdf (accessed on 17 August 2019).

44. Croatian Bureau of Statistics. Population Census 2011. Available online: https://www.dzs.hr/Eng/censuses/ census2011/firstres/censusmetod.htm (accessed on 17 August 2019).

45. Centar za vozila Hrvatske - Statistika: Prosječno godišnje prijeđeni put po vrstama vozila za 2019. godinu. Available at. Available online: https://www.cvh.hr/tehnicki-pregled/statistika/ (accessed on 21 December 2019). (In Croatian)

46. Propellets Austria. International Pellet Prices. Available online: https://www.propellets.at/en/internationalprices-wood-pellets (accessed on 16 August 2019).

47. BALTPOOL: Lithuanian Energy Exchange Entitled to Organise Trade of Solid Biofuel Products. Available online: https://www.baltpool.eu/en/supply-price-by-regions/ (accessed on 30 December 2019).

48. Banovina Raafourty Holding d.o.o. Cjenik energetskog i celuloznog drva _ 2019. Available online: http://raa.hr/06b_RAA_Cjenik\%20energetskog\%20drva_2017.pdf (accessed on 17 August 2019). (In Croatian) 
49. Croatian Bureau of Statistics: Popis poljoprivrede 2003. Available online: https://www.dzs.hr/Hrv/censuses/ Agriculture2003/census_agr_met.htm (accessed on 17 August 2019). (In Croatian)

50. Ministry of Agriculture. Godišnje izvješće o stanju poljoprivrede u 2018. godini. Available online: https://poljoprivreda.gov.hr/UserDocsImages/dokumenti/poljoprivredna_politika/zeleno_izvjesce/ 2019_11_13_Zeleno\%20izvjesce2018.pdf/ (accessed on 19 November 2019).

51. Croatian Bureau of Statistic. Statistical Yearbook of the Republic of Croatia 2018; Croatian Bureau of Statistics: Zagreb, Croatia, 2018; ISSN 1333-3305.

52. DZS: INDICATORS OF POVERTY AND SOCIAL EXCLUSION, 2016-Final Results. Available online: https://www.dzs.hr/Hrv_Eng/publication/2017/14-01-01_01_2017.htm (accessed on 20 September 2018).

53. DOOR Energy Poverty. Available online: https://www.interregeurope.eu/fileadmin/user_upload/tx_ tevprojects/library/file_1502890570.pdf (accessed on 20 August 2019).

(C) 2020 by the authors. Licensee MDPI, Basel, Switzerland. This article is an open access article distributed under the terms and conditions of the Creative Commons Attribution (CC BY) license (http://creativecommons.org/licenses/by/4.0/). 